\title{
The Role of U.S. Patent Protection in Commercializing University Technologies
}

Lei Fang, Esq., PhD, MD, Chris Chan, Esq.

The United States has been successful in spurring the growth of research and development within its universities and, as a result, universities have seen significant returns. In 2012, U.S. universities earned about US $\$ 2.6$ billion by licensing their technologies. In addition, 5,130 technology licenses were executed; 14,224 new patent applications were filed; 5,145 U.S. patents were issued; and 705 start-up companies were created. ${ }^{2}$

All of these achievements are a direct result of the enactment of the Bayh-Dole Act by the U.S. Congress. Since 1980, the BayhDole Act has been instrumental in encouraging universities to participate in technology transfer activities by creating a uniform patent policy to promote cooperation among academia, small businesses, and industry. In addition, the Bayh-Dole Act provides universities and research institutions patent rights to certain inventions arising out of government-sponsored research and development.

Major provisions of the Bayh-Dole Act include: (1) providing non-profits, including universities, and small businesses the option to retain title to innovations developed under U.S. government-funded research programs; (2) encouraging universities to collaborate with commercial entities to promote the utilization of inventions arising from federal funding; (3) encouraging universities to file patents on inventions they elect to own; (4) encouraging universities to give licensing preference to small businesses; (5) providing the U.S. government with a non-exclusive license to practice certain patents throughout the world; and (6) providing the U.S. government with certain rights, known as "march-in" rights, to inventions sponsored by or otherwise funded by the government. ${ }^{3}$

Patents are fundamental building blocks for universities seeking licensing revenue and opportunities. A patent is a limited monopoly granted by the U.S. government to exclude others from making, using, selling, offering to sell, or importing into the U.S. a claimed invention. Three types of patents are available in the U.S. First, utility patents protect utilitarian or functional aspects of an invention. Next, design patents protect ornamental aspects and product configurations. Finally, plant patents protect asexually reproducing plants. Utility and plant patents protect the underlying inventions for 20 years from the earliest date of priority, usually the filing date of a non-provisional or plant application. Design patents protect the underlying claimed designs for 14 years from the date the patent is issued.

Two types of utility patent applications can be filed in the U.S.: provisional and non-provisional applications. A provisional application is usually filed as a placeholder to obtain a filing date for an invention, and may or may not include patent claims, which are the legal definition of the scope of the claimed invention. A provisional application should describe all known inventive subject matter including hypothetical embodiments and examples. Though provisional applications are not substantively examined by the U.S. Patent and Trademark Office (USPTO), the main purpose of a provisional application is to establish an effective filing date, which is important under the new "first-to-file" U.S. patent law. One or more provisional applications filed during a 12 -month period can be combined into a single non-provisional application, or a non-provisional application can be filed in the absence of filing any provisional application. In any instance, a non-provisional application includes claims or the legal definition of the scope of the claimed invention as well as a detailed description and drawings of the invention. The non-provisional application is examined by the USPTO and can eventually issue as a patent.

During the examination process by the USPTO, each non-provisional application is reviewed by a patent examiner against any prior art identified by the examiner's search or disclosed to the examiner by the inventor. Beginning with the filing of the application, it takes about 12 to 36 months for the USPTO to review and examine the application. The examination process usually results in an Examiner's Office Action, which includes any objections or rejections of the claims. The applicant presents counterarguments and any claim amendments in a written response to the examiner. In some cases, there may be several exchanges of Office Actions and applicant responses. After a final rejection, an applicant can either file a Request for Continued Examination (RCE) to continue the examination, or appeal the rejections to the Patent Trial and Appeal Board (PTAB). If successful, the applicant will obtain an allowance of the pending claims and eventually a patent will be granted on the invention.

There are several requirements for obtaining U.S. patent protection. First, each filed patent application is limited to a single claimed invention. This is similar to the unity of invention requirements in other countries. Next, U.S. law limits what can be patented. Recent U.S. Supreme Court decisions have limited the patentability of certain technologies and subject matter, such as risk hedging methods in energy markets, tests correlating blood levels and medications, and DNA. Further guidance from the Supreme Court on patenting software and computer-implemented inventions is expected this year. An additional requirement under U.S. law is that the invention must have some utility or be useful. This is typically an easy requirement to meet. Next, each invention is examined against novelty and non-obviousness requirements, based on prior art or what has been published, patented, or used publicly prior to the filing date of the patent application for the invention. Other statutory requirements under U.S. law are that the patent application sufficiently describe the invention and suitably disclose how to make and use the invention.

While many of these requirements are similar to laws in other countries, U.S. law has two additional requirements. First, the correct inventors must be named at the time of filing the patent application. Failure to correctly identify all of the inventors could invalidate any subsequently issued patent for the invention. Finally, a duty of disclosure applies to all U.S. patent applicants and their attorneys. This means that during the examination of a patent application, all prior art known by applicants and their attorneys must be disclosed to the examiner. Again, failure to disclose prior art could invalidate a subsequently issued patent for the invention.

For more information on U.S. patent practice, please contact us. 
Address for correspondence

Corresponding author: Lei Fang, Esq., PhD, MD, Sutherland

Asbill \& Brennan LLP, 999 Peachtree Street, NE, Suite 2300 Atlanta, GA 30309-3996

Email: Lei.Fang@sutherland.com

Disclosure of Funding

Sutherland Asbill \& Brennan LLP

Additional publication details

Journal short name: Trans Periop \& Pain Med

Received Date:June 1, 2014

Accepted Date: June 15, 2014

Published Date: July 1, 2014

Trans Periop \& Pain Med 2014, 1(1): 11-12

\section{Citation and Copyrights}

Citation: Fang, Lei: The Role of U.S. Patent Protection in Commericializing University Technologies. Trans Periop \& Pain Med 2014, 1(1): 12-13

Copyright: @ 2014 Fang, Lei et al. This is an open-access article distributed under the terms of the Creative Commons Attribution License, which permits unrestricted use, distribution, and reproduction in any medium, provided the original author and source are credited.

End Notes

1. Lei Fang and Chris Chan are intellectual property attorneys at the international law firm of Sutherland Asbill \& Brennan LLP, based in Atlanta, Georgia. In addition to her law degree, Ms. Fang has a medical degree and a Ph.D. in Pharmacology. Ms. Fang represents start-up companies as well as large corporations, universities, and research institutes in various technologies, such as pharmaceuticals, biotechnology, neuroscience, chemicals, nanotechnology, medical devices, and life sciences. In addition to his law degree, Mr. Chan has a mechanical engineering degree. Mr. Chan represents clients in a variety of industries and technologies including computers, software, electrical-mechanical innovations, business methods, and medical devices. Both Ms. Fang and Mr. Chan assist clients seeking patent, trademark, and copyright protection; licensing and technology transfers; IP due diligence; and pre-litigation counseling.

2. $\quad$ AUTM U.S. Licensing Activity Survey: FY 2012, http://www.autm.net/FY2012_Licensing_Activity_Survey/12357.htm, last accessed June 1,2014

3. http://www.autm.net/Bayh_Dole_Act/11606.htm, last accessed Jun 1, 2014 